
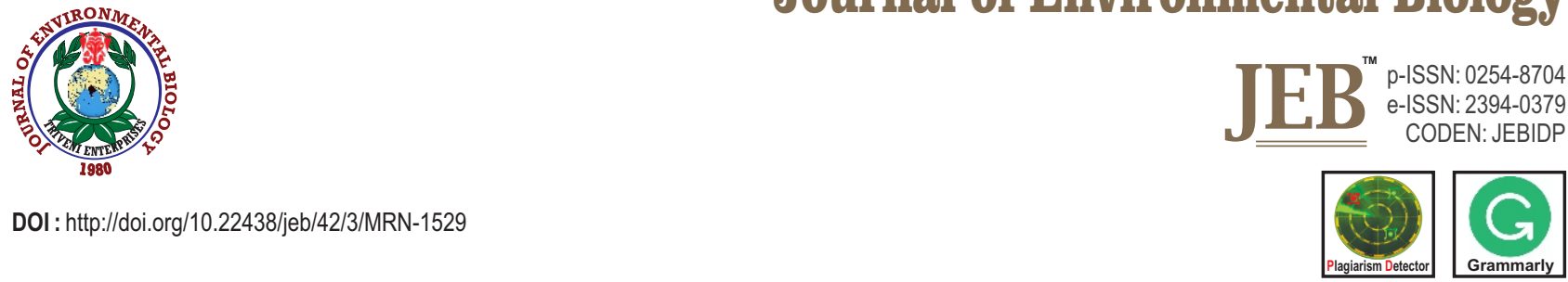

\title{
Bioprospecting of microbial isolates from biodynamic preparations for PGPR and biocontrol properties
}

\author{
S. Vaish ${ }^{1,2}$, N. Garg ${ }^{1 *}$ and I.Z. Ahmad ${ }^{3}$ \\ ${ }^{1}$ Division of Post Harvest Managment, ICAR-Central Institute for Subtropical Horticulture, Lucknow-226 101, India \\ ${ }^{2}$ Department of Biosciences, Integral University, Lucknow-226 026, India \\ ${ }^{3}$ Department of Bioengineering, Integral University, Lucknow-226 026, India \\ *Corresponding Author Email : neelimagargg@gmail.com
}

\section{Abstract}

Aim: To study the role of microorganisms behind their bioenhancing, biocontrol properties, their enzymatic potential, and characterization of high performing microbial isolates on molecular basis.

Methodology: Dominant culturable microbes including bacteria and fungi were isolated from biodynamic preparations and screened on the basis of plant-growth promoting (PGP) activities viz., ammonia production, phosphate solubilization, siderophore production, hydrogen cyanide production, seed germination efficacy and biocontrol properties. The dominant and effective microorganisms were screened for enzymes activities viz., pectinase, cellulase and amylase. The selected bacterial and fungal isolates, exhibiting higher enzyme activities, were subjected to molecular characterization.

Results: Out of 68 bacterial and 25 fungal isolates from 8 biodynamic preparations (BD 500 - BD 507), 15 bacterial isolates exhibited high plant growth promoting activities while 10 bacterial isolates exhibited biocontrol activity against pathogens. Bacillus licheniformis isolated from BD 504, expressed high pectinase $\left(2.595 \mathrm{U} \mathrm{ml}^{-1} \mathrm{~min}^{-1}\right)$, cellulase $\left(0.308 \mathrm{U} \mathrm{ml}^{-1} \mathrm{~min}^{-1}\right)$ and amylase $\left(0.418 \mathrm{U} \mathrm{ml}^{-1} \mathrm{~min}^{-1}\right)$ activities. Fungal isolates with high enzymatic activities, were isolated from BD 500, 503 and 506 , respectively.

Interpretation: Microorganism isolates from biodynamic preparations possessed strong plant growth promoting, biocontrol and enzymatic properties, which might be responsible for the efficacy of organic preparations under field conditions.

Key words: Bacillus licheniformis, Biodynamic preparations, Microbes, Molecular identification, PGP activity

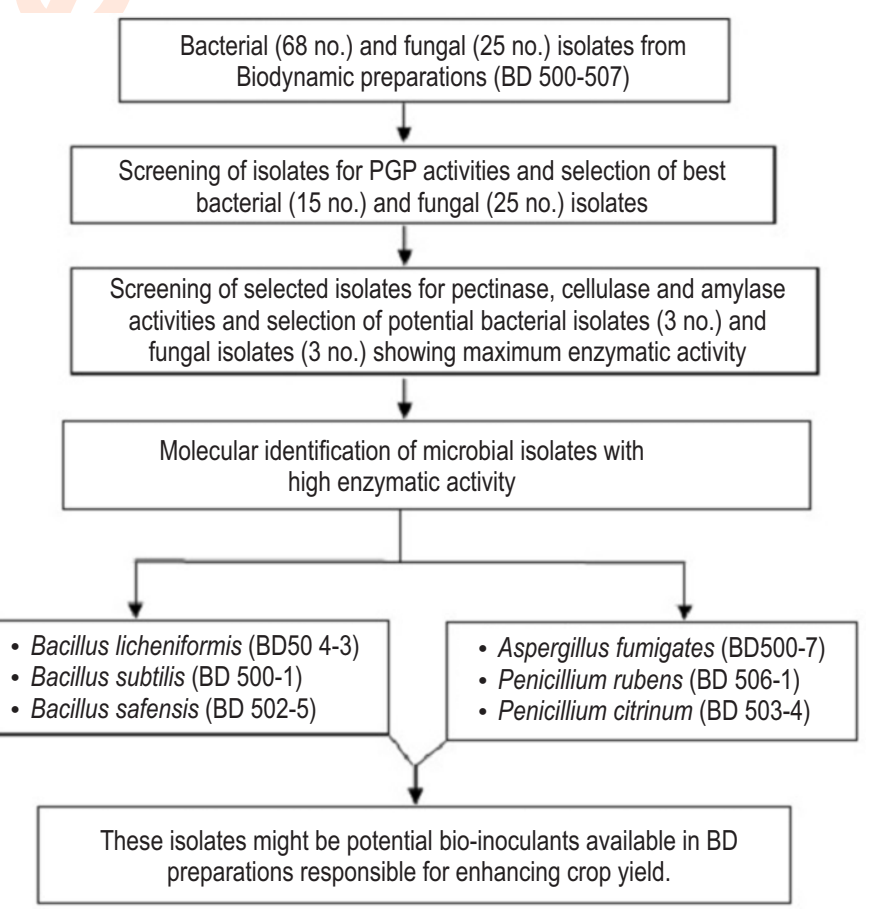

How to cite : Vaish, S., N. Garg and I.Z. Ahmad: Bioprospecting of microbial isolates from biodynamic preparations for PGPR and biocontrol properties. J. Environ. Biol., 42, 644-651 (2021).
Journal of Environmental Biology

May

Journal Environgental Biology




\section{Introduction}

Excessive use of chemical inputs in the form of fertilizers and pesticides over the past few decades has resulted in the loss of natural habitat balance, environment degradation, reduced food quality and increased cost of crop cultivation (Speth, 1992; Ahmed et al., 2012). However, the increasing awareness about the ill-effects of modern agriculture has led to the resurgence of interest in organic agriculture and demand for organic produce (King, 2008; Reddy, 2010; Pandey and Singh, 2012). There are various systems of organic farming, including Permaculture, Rishi Krishi, Panchgavya, Nauteco, Zero Budget Natural Farming and Biodynamic Farming, being practiced in different parts of country and in the world (Nene, 2017). Biodynamics farming is the one of the oldest organized agriculture farming system started in Germany by Rudolf Steiner in 1924 (Koepf, 1989).

Today biodynamic agriculture is practiced on farms around the world, on various scales, and in a variety of climates and cultures. However, most biodynamic farms are located in Europe, the United States, Australia and New Zealand (Diver, 1999). Biodynamic agriculture uses specific manure and fermented herbal preparations as compost additives and field sprays in comparison to organic agriculture (Proctor, 1989). The system makes use of eight biodynamic preparations viz. BD500, 501, 502, 503, 504, 505, 506 and 507 (Krichman, 1994). Cow horns, by virtue of their shape, functioned as antennae for receiving and focusing cosmic forces, transferring them to the materials inside (Chalker Scott, 2013). After exhumation, the contents are diluted with an unspecified amount of water to create a homeopathic solution, which when applied to soil (Preparation 500 ) or crops (Preparation 501), was thought to influence root or leaf growth. Six other compounds (Preparations 502-507) are extracts of various plants packed either in the skulls or organs of animals (e.g., deer bladders, cow peritonea and intestines) or peat or manure, where they age before being diluted and applied as compost microbial inoculums (Chalker Scott, 2013). BD 500 is used as spray to vitalize the soil, enhance seed germination, root formation and primary root development, while BD 501 is sprayed to improve photosynthesis and immunity in plants, quality of fruits and seeds (Selvaraj et al., 2006). BD 502- 507 is used for making biodynamic compost.

Addition of biodynamic preparations in composting raw material leads to better stability of organic matter, improves the chemical and microbial quality of compost with reduced $\mathrm{CO}_{2}$ production and higher enzyme activity (Carpenter-Boggs et al., 2000a; Fließbach et al., 2000). Biodynamic farming system promotes and improves the health of the agro-ecosystems related to biodiversity, nutrient biocycles, soil microbial and biochemical activities, strongly affect root and vegetative growth (Raupp and Konig, 1996; Ponzio et al., 2013; Goldstein et al., 2019), however, the mechanism of action of these BD preparations needs to be established. An assumption may occur that $\mathrm{BD}$ preparations might posses some supernatural or magical curing ability, but these preparations work on scientific principles mostly powered by microbes and their metabolic products, as these are fermented products. In view of the above, the present study was conducted with the objective of bio prospecting these $\mathrm{BD}$ preparation for microbiological and biochemical properties, which in turn might be responsible for improvement in yield and quality of crops.

\section{Materials and Methods}

Microbial analysis, isolation and maintenance of microbial isolates of BD preparations: For microbial analysis and isolation of dominant microbes, media enrichment techniques and serial dilution assay (Marvin, 1984) were followed. Nutrient agar medium and Rose Bengal Chloramphenicol agar were used for growth studies of bacteria and mould. The microbial isolates were maintained on their respective growth medium slants and stored at $4^{\circ} \mathrm{C}$ for further testing. The isolates were numbered as follows: Number of BD preparation followed by isolate no., for example isolate no. 4 from BD 500 was named as BD 500 - 4 .

Testing plant growth promoting (PGP) activities: Siderophore production, IAA production, HCN production and phosphate solubilization assays were conducted as per method described by Schwyn and Neilands (1987), Bric et al. (1991), Bakker and Schipper (1987) and Gaur (1990). Ammonia production test was carried by the method of Dye (1962). Gram (Cicer arietinum) seeds were used for testing seed germination efficiency under in-vitro and in-vivo conditions, as per method described by Shende et al. (1977). Growth yield parameters like root length and shoot length were measured after harvesting of one-month-old gram plant, while fresh weight of root and shoot, number of leaves per plant were taken immediately after harvesting of plant. Dry weight of root and shoot were measured after complete drying of sample in hot air oven at $50^{\circ} \mathrm{C}$.

After harvesting the plants, the pot soil was analyzed for biological properties following standard protocols, viz. soil microbial load (Marvin, 1984), dehydogenase activity (Lenhard, 1956), fluorescene diacetate activity (Schnürer and Rosswall, 1982) and physical parameters viz. pH, EC and soil moisture (Jackson, 1967). Growth yield parameters like length and fresh weight of root and shoot, number of leaves per plant, were taken immediately after harvesting one-month-old plant. Dry weight of root and shoot were taken after complete drying of sample in hot air oven at $50^{\circ} \mathrm{C}$. Antimicrobial activity of isolated microbes was observed by plate assay method of Boruah and Kumar (2002).

Enzymatic extraction and estimation: Carbohydrate utilization broth, with 1\% pectin/starch/carboxymethyl cellulose as carbon source, was inoculated with bacterial and fungal isolates and incubated at $28^{\circ} \mathrm{C}$ for $72 \mathrm{hrs}$. For bacterial culture, broth was centrifuged at 10,000 rpm for $10 \mathrm{~min}$ and the supernatant was used for enzyme extraction. For fungus, culture broth was filtered through G-1 glass crucible to remove the fungal growth and filtrate was used for enzyme extraction. One volume of culture filtrate from bacteria/fungus was added in 4 volume (1:4) of cold 
acetone mixture, kept at $-20^{\circ} \mathrm{C}$ for 20 min, centrifuged at 10,000 rpm for $15 \mathrm{~min}$ at $4^{\circ} \mathrm{C}$. The supernatant was discarded and the pellet was suspended in acetate buffer solution $(0.2 \mathrm{mM})$. The mixture was used as enzyme precipitate for enzymatic analysis for cellulase, pectinase and amylase activity using carboxy methyl cellulose, pectin and starch as substrate as per method described by Miller (1959); Garg and Ashfaque (2010) and Wood and Bhat (1988), respectively. The enzyme activity was expressed as $\mathrm{U}$ (unit) sugar released $\mathrm{ml}^{-1} \mathrm{~min}^{-1}$ of incubation.

Molecular characterization of best performing microbial isolates: Bacterial isolates exhibiting high PGP, biocontrol and enzymatic activities, and fungal culture exhibiting good pectinase, cellulase, amylase activity and siderophore production efficacy were subjected to molecular identification using techniques viz. 16s rRNA for bacteria and ITS primer for fungi. Microbial DNA was isolated and its quality was evaluated on $1.2 \%$ Agarose Gel to obtain a band of high-molecular weight. Isolated DNA was amplified with $16 \mathrm{~S}$ rRNA Specific primer (8F and 1492R) for bacteria and ITS region specific primer (ITS1 and ITS4) for fungus using Veriti® 96 well Thermal Cycler (Model No. 9902). PCR amplicon was enzymatically purified and further subjected to Sanger Sequencing. The $16 \mathrm{~S}$ rDNA sequence and ITS region sequence for bacteria and fungus were used to carry out BLAST alignment search tool of NCBI Genbank database. Based on the maximum identity score, first fifteen sequences were selected and aligned using multiple alignment software program Clustal W. Distance matrix was generated using RDP database and phylogenetic tree was constructed using MEGA6 and 7 for fungus and bacteria, respectively (Tamura et al., 2011). All the treatments were kept in triplicate. Statistical analyses were done as described by Panse and Sukhatme (1967).

\section{Results and Discussion}

Out of eight biodynamic preparations, the highest bacterial load (CFU ml ${ }^{-1}$ or $\left.^{-1}\right)$ was observed in $\operatorname{BD} 502\left(2.6^{*} 10^{9}\right)$ followed by

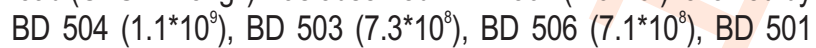
$\left(5.4^{*} 10^{8}\right), \operatorname{BD} 507\left(3.4^{*} 10^{8}\right), \operatorname{BD} 500\left(3.2^{*} 10^{8}\right)$ and BD $505\left(2.7^{*} 10^{8}\right)$. The highest fungal count (CFU ml ${ }^{-1}$ or g $^{-1}$ ) was observed in BD 503 $\left(2.8^{*} 10^{6}\right)$, followed by BD $500\left(5.6^{*} 10^{5}\right)$, BD $504\left(4.5^{\star} 10^{5}\right)$, BD 506 $\left(3.6^{*} 10^{5}\right), \operatorname{BD} 505\left(3.6^{*} 10^{5}\right), \operatorname{BD} 502\left(3.4^{*} 10^{5}\right), \operatorname{BD} 501\left(1.1^{*} 10^{5}\right)$ and BD $507\left(0.8^{*} 10^{5}\right)$. Higher counts were observed in biodynamic preparations compared to those reported by Pathak et al. (2010), which might be due to the fact that biodynamic preparations are fermented product and microbial load may vary as per fermentation conditions and quality of raw materials.

However, the observation that maximum bacterial load was observed in BD 502 and fungal load in BD 503 corroborates the results of Pathak et al. (2010) who reported the highest bacterial load was found in BD $502\left(3.4^{*} 10^{6}\right)$ and second highest fungal load in BD $503\left(1^{*} 10^{5}\right)$. Giannattasio et al. (2013) reported microbial load of $2.3^{*} 10^{8} \mathrm{CFU} \mathrm{g}^{-1}$ in BD 500. Garg et al. (2004 a, b) and Ram et al. (2007), reported increase in rhizosphere microbial population of field and orchard soils after the application of BD preparations. Veeresh et al. (2010) observed positive influence of biodynamic microbial consortium on the microbial population during the conversion of paper mill and sugar factory sludge into beneficial vermicompost. For screening the microbial isolates for plant growth promoting activity, out of 68 bacterial and 25 fungal isolates, positive results were exhibited by $65,29,26,42$ and 36 number of isolates for ammonia production, phosphate solubilization, siderophore, indole acetic acid and HCN production, respectively.

Higher ammonia production activity was expressed by isolate no. BD 500 - 10, BD 502 - 5 and BD $505-6$, higher phosphate solubilization were shown by BD 502 - 5 and BD 502 7 , higher siderophore production was shown by isolate no. BD 503 - 4 and BD 503 - 6, Higher indole acetic acid production was observed in isolate no. BD500- 9, BD503 - 4, BD503 - 6 and BD504-16. Higher activity of hydrogen cyanide was exhibited by isolate no. BD 500-1, BD 500 - 6, BD 502 - 5, BD502-7, BD 504 - 3 and BD505-6. Similar observation has been reported by Radha and Rao (2014) where Lysinibacillus xylanilyticus and Bacillus licheniformis isolates from biodynamic preparations exhibited plant growth promoting activity like IAA production, P solubilisation. Similarly, Carpenter - Boggs (2000b) correlated the use of BD sprays 500, 501 and 508 with higher yield of lentil (Lens culinaris) per unit plant biomass, higher nitrate content in soft white spring wheat and greater ammonia concentration in soil. Out of 25 fungal isolates, 18 showed positive test for siderophore production. Microbial isolates viz., BD 506-1, BD 500-2 and BD 504-5 exhibited high siderophore production efficiency of 190,200 and $285.7 \%$, respectively. Other PGP activities viz. IAA production, HCN production and phosphate solubilization were not expressed by any of the fungal

Table 1: Effect of inoculation of bacterial isolates from $\mathrm{BD}$ preparations on germination of Cicer arietinum seeds under in-vitro conditions

\begin{tabular}{llll}
\hline Isolate no. & $\begin{array}{l}\text { Germination } \\
\text { Index (\%) }\end{array}$ & $\begin{array}{l}\text { Root length } \\
(\mathbf{c m})\end{array}$ & $\begin{array}{l}\text { Shoot length } \\
(\mathbf{c m})\end{array}$ \\
\hline Control & 20 & 3.4 & 1.5 \\
BD 500-1 & 8.0 & 4.1 & 0.8 \\
BD 500-3 & 8.0 & 4.3 & 2.1 \\
BD 500-5 & 20 & 4.6 & 1.1 \\
BD 500-6 & 4.0 & 4.6 & 1.0 \\
BD 500-9 & 28 & 4.2 & 2.1 \\
BD 500- 10 & 16 & 4.7 & 2.3 \\
BD 501-2 & 20 & 2.9 & 1.1 \\
BD 502-5 & 36 & 2.8 & 1.3 \\
BD 502-7 & 32 & 3.1 & 1.5 \\
BD 503-4 & 24 & 5.3 & 1.4 \\
BD 503-6 & 20 & 3.5 & 2.0 \\
BD 504- 3 & 12 & 4.5 & 2.7 \\
BD 504- 16 & 12 & 3.6 & 2.2 \\
BD 505-5 & 24 & 4.2 & 2.2 \\
BD 505- 6 & 8.0 & 3.4 & 1.3 \\
CD value & 0.886 & 0.909 & 0.774 \\
\hline
\end{tabular}




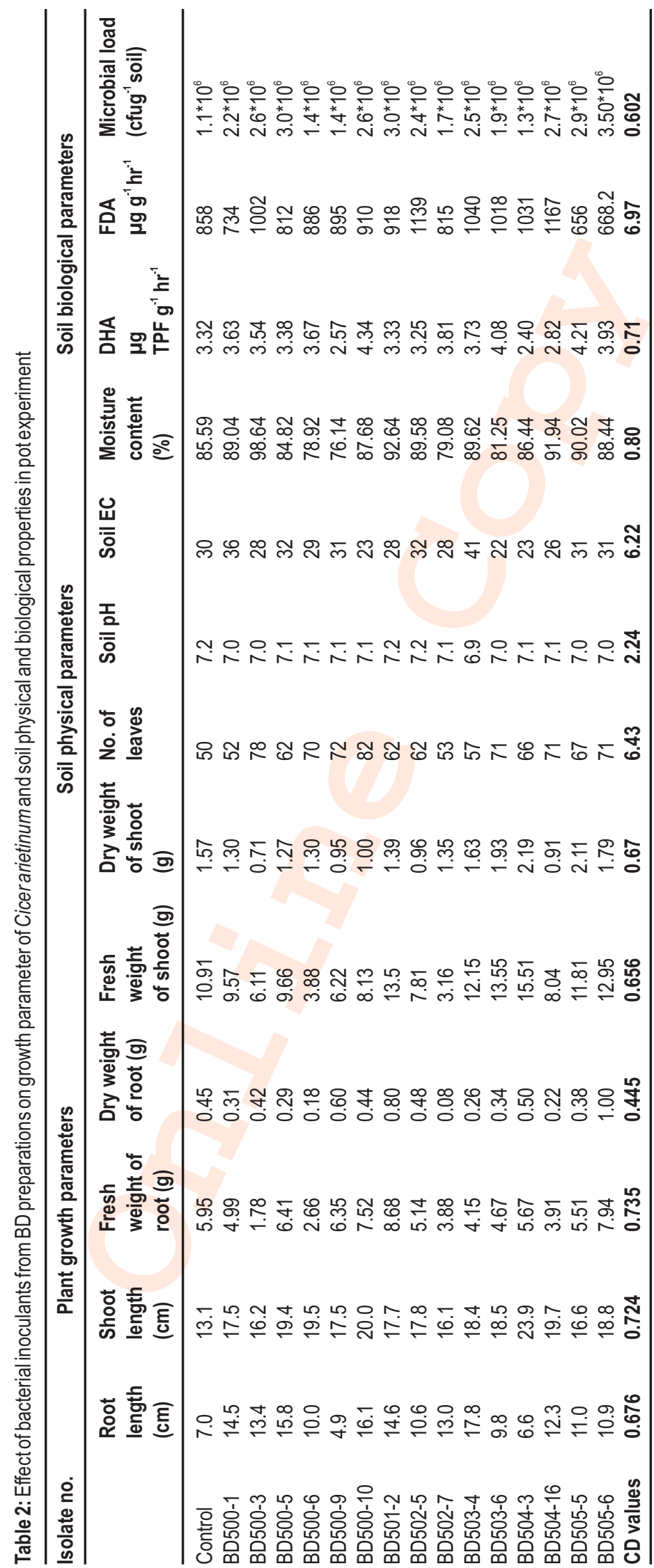

- Journal of Environmental Biology, May 2021 • 
Table 3: Enzymatic activities $\left(\mathrm{U} \mathrm{ml}^{-1} \mathrm{~min}^{-1}\right)$ of selected bacterial and fungal isolates from biodynamic preparations

\begin{tabular}{lllll}
\hline Type of isolates & Isolate no. & Pectinase activity & Amylase activity & Cellulase activity \\
\hline Bacteria & BD 500-1 & 2.361 & 0.181 & 0.287 \\
& BD 502-5 & 2.307 & 0.376 & 0.230 \\
\multirow{3}{*}{ Fungus } & BD 504-3 & 2.595 & 0.418 & 0.308 \\
& BD 500-7 & 0.939 & 0.0666 & 0.0357 \\
& BD 503-4 & 0.708 & 0.0459 & 0.1284 \\
& BD 506-1 & 0.678 & 0.1107 & 0.0843 \\
\hline
\end{tabular}

isolates. Fifteen best bacterial isolates, screened from above PGP activities testing, were tested for seed germination potential. Under in-vitro conditions, higher seed germination index were shown by BD 500-9 (28\%), BD 503-4 (24\%) and BD 505-5 (24\%) in comparison to control (20\%). Higher root length were observed in gram seeds treated with BD 503-4, BD 500-10 and BD 500-5 in comparison to control. Higher shoot length was shown by BD 504-3, BD 500-10 and BD 50416 in comparison to control (Table 1). Under pot experiment, similar trend of seed germination was observed.

Higher root length was exhibited by the seeds treated with bacterial isolates BD $503-4(17.8 \mathrm{~cm}), \mathrm{BD} 500-10(16.1 \mathrm{~cm})$ and BD $500-5(15.85 \mathrm{~cm})$. Table 2 depicts higher shoot length by seeds treatment with bacterial isolates BD $504-3(23.9 \mathrm{~cm}), \mathrm{BD}$ $500-10(20 \mathrm{~cm})$ and BD $504-16(19.7 \mathrm{~cm})$. The maximum number of leaves were observed in seeds having treatments of BD 500-10 (82 no.), BD 500-3 (78 no.) and BD 505-6 (71 no.). Higher microbial population were observed in soil having seeds treatments with $\mathrm{BD} 505-6\left(3.5^{*} 10^{6}\right)$. Other growth parameters like fresh weight and dry weight of roots were high in seed treated with BD 501-2 and BD 505-6. The fresh and dry weight of stem were found to be high in seed treated with BD 504-3 and BD 503-6, respectively. This result is supported by Yadav et al. (2010) where PGPR isolates affected the growth of chickpea plant by way of increase in length and dry matter of root and shoot. Other isolates also exhibited improvement in soil physical, biochemical and biological parameters. This might be due to improved inorganic nutrient availability as a result of biodegradative enzyme produced by microorganism present in BD preparations.

The soil physical parameters like $\mathrm{pH}$ and $\mathrm{EC}$ were not much affected, while the moisture content ranged between 76.14 to $98.64 \%$. Soil dehydrogenase and soil fluorescene diacetate activities, indicator of microbial activity, were highest with BD 500 -

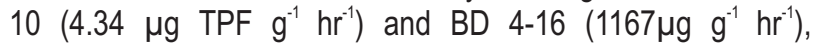
respectively. Dehydrogenase is an enzyme brings about oxidoreduction process intracellularly while fluorescene diacetate assay determines the amount of acetyl esterase in microbial cell. The microflora of BD preparations might be responsible for dehydreogenase activity in treated soils. Higher dehydrogenase activity in $\mathrm{BD}$ treated compost and soil receiving organic and biodynamic preparations has been reported by Carpenter-Boggs et al. (2000b) and Rana et al. (2015), respectively. Wheat seedlings receiving 1\% BD-treated compost extract have been reported to have higher root and shoot biomass (Reeve et al., 2011). Similarly, Valdez and Fernandez (2008) reported higher root length and biomass in rice varieties under biodynamic production system control or pesticide treatment. For biocontrol efficacy of bacterial and fungal isolates against Fusaium solani, Colletotrichum gleosporiodium and Pestalotiopsis mangiferae, out of 68 bacterial isolates, 10 exhibited biocontrol activity against Fusaium solani, while bacterial isolate BD502-5, later identified as Bacillus safensis, was found effective against all three pathogens tested. However, none of the remaining bacterial and all fungal isolates exhibited biocontrol property. Biocontrol properties of microbial isolates from $\mathrm{BD}$ preparations have been reported earlier. Rupela et al. (2003) isolated a total of 17 bacterial isolates from BD 500 , BD 502-506 showing antagonistic activity against phytopathogenic fungi Rhizoctonia bataticola, Sclerotium rolfsii, Fusarium oxysporum and Aspergillus flavus. Similarly, Valdez and Fernandez (2008) showed that the application of BD 500, 501 and 508 resulted in the disappearance of tungro symptom in rice crops and recovery of crop vitality. Radha and Rao (2014) reported antagonistic activity of Lysinibacillus xylanilyticus and Bacillus licheniformis isolates from biodynamic preparations to Rhizoctonia bataticolain maize plants.

Microbial isolates showing high PGP activity were screened for enzymatic activities. Among the three bacterial isolates, isolate no. BD 504-3 showed high pectinase, cellulase and amylase activity (Table 3). The isolate was identified as Bacillus licheniformis. There are several reports of high enzymatic activities of Bacillus licheniformis. Vengadaramana et al. (2011) reported high a-amylase activity (32.95 $\mathrm{U} \mathrm{ml}^{-1}$ ) by Bacillus licheniformis. Nallusamy et al. (2016) reported eight cellulolytic $B$. licheniformis strains from compost samples which were able to utilize xylan, cellobiose, mannose and carboxy methyl cellulose. Rehman et al. (2015) isolated Bacillus licheniformis from rotten vegetables that produced higher pectinase enzyme. Out of 25 fungal isolates from biodynamic preparations, high pectinase, cellulase and amylase activities were exhibited by isolate no. BD500-7, BD506-1 and BD503-4, respectively (Table 3 ). High enzyme activity shown by various fungi, isolated from different BD preparations explains the degradative powers associated with these preparations.

For molecular identification of high performing microbial isolates, the bacterial isolates exhibiting good PGP and 
biocontrol activity were subjected to molecular identification using 16S rRNA method and the sequences were deposited in $\mathrm{NCBI}$ database. Bacterial isolate BD 504-3 was identified as Bacillus licheniformis strain NG102 (Accession Number: MN176508) and BD 500-1 as Bacillus subtilis strain NG101 (Accession Number: MN176513) based on nucleotide homology and phylogenetic analysis. Bacterial isolate BD 502-5 was identified as Bacillus safensis strain NG8 (Accession number: Mn258985). The results are in consensus with that of Radha and Rao (2014) who isolated Bacillus safensis, Bacillus subtilis and Bacillus licheniformis from organic and biodynamic preparations. These bacterial isolates exhibited phosphorous solubilization from insoluble tricalcium phosphate and antagonism to the plant pathogen, Rhizoctonia bataticola.

Fungal isolate no. BD 500-7, with high pectinase activity, was identified as Aspergillus fumigatus strain NG14 (Accession number: Mn272432). Ezugwu et al. (2014) also reported high pectinase production by $A$. fumigatus in a submerged fermentation system. Fungal isolate BD 506-1, exhibiting high cellulase activity, was identified as Penicillium rubens strain NG10 (Accession Number: MN272400). Various Penicillium species has proved to be an efficient producer of extracellular cellulases. Chinedu et al. (2011) reported three fungi, including Penicillium chrysogenumas potential producers of cellulase enzyme for degrading wood-waste dump in Lagos, Nigeria. In this study, high amylase activity was exhibited by BD 503-4 and it was identified as Penicillium citrinum strain NG12 (Accession Number: MN272406). Kubilay et al. (2010) reported high amylolytic activity of Penicillium citrinum in starch agar medium. Fungal isolate no. BD5045 showing high siderophore efficacy was identified as Alternaria brassicae strain NG13 (Accession Number: MN272425). Pedras and Park (2015) also reported siderophores production in cultures of $A$. brassicicola containing low and high ferric ion concentrations. This study provides basis for the beneficial effects of biodynamic preparations in field conditions. The results clearly indicate that the microorganisms present in biodynamic preparations possess strong plant growth promoting activities, biocontrol and enzymatic properties, which in turn might be responsible for the effectiveness of organic preparations under field conditions. Efficient microorganisms present in these preparations are constantly working as bioinoculums to perform mineralization for restoring or maintaining soil fertility, act as nitrogen fixers, phosphate solubilizers, produce some bioactive compounds which promote plant growth and inhibit soil pathogens.

\section{Acknowledgments}

Authors are thankful to the Director, CISH for providing research facilities. The authors also acknowledge the office of Doctoral Studies and Research, Integral University for critically reviewing the manuscript, providing the manuscript number (IU/R\&D/2019- MCN000559). BD set comprising of BD 500 - BD 507 was procured from Supa Biotech, Nanital.

\section{Add-on Information}

Authors' contribution: S. Vaish: Investigation, Standarization of methodology, Experimentation, formal analysis, writing, review, editing; N. Garg: Conceptulization, Writing original draft, Supervision and editing; I.Z. Ahmad: Supervision, data curation, Review and Editing.

Research content: The research content of manuscript is original and has not been published elsewhere.

Ethical approval: Not applicable

Conflict of interest: Authors have no conflict of interest.

Data from other sources: Not applicable

Consent to publish: All authors agree to publish the paper in Journal of Environmental Biology.

\section{References}

Ahmed, W., C.L. Soskolne and T. Ahmed: Strategic thinking on sustainability, challenges and sectoral roles. Environ. Dev. Sustain., 14,67-83 (2012).

Bakker, A.W. and B. Schippers: Microbial cyanide production in the rhizosphere in relation to potato yield reduction and Pseudomonas spp. mediated plant growth stimulation. Soil Biol. Biochem., 19, 451-457 (1987).

Boruah, D., H.P. and B.S.D. Kumar: Plant disease suppression and growth promotion by a fluorescent Pseudomonas strain, Folia Microbiol., 47, 137-143 (2002).

Bric, J.M., R.M. Bostock and S.E. Silversone: Rapid in situ assay for indole acetic acid production by bacteria immobilized on a nitrocellulose membrane. Appl. Environ. Microbiol., 57, 535-538 (1991).

Carpenter-Boggs, L., J.P. Reganold and A.C. Kennedy: Effects of biodynamic preparations on compost development. Biol. Agric. Hortic., 17, 313-328 (2000a).

Carpenter-Boggs, L., J.P. Reganold and A.C. Kennedy: Organic and biodynamic management: Effects on soil biology. Soil Sci. Soc. Am. J., 64, 1651-1659 (2000b).

Chalker-Scott, L.: The science behind biodynamic preparations: a literature review. Hort Technology., 23, 814-819(2013)

Chinedu, S.N., V.I. Okochi and O. Omidiji: Cellulase production by wild strains of Aspergillus niger, Penicillium chrysogenum and Trichoderma harzianum grown on waste cellulosic materials. Ife J. Sci., 13, 57-62 (2011).

Diver, S.: Biodynamic farming and compost preparation. Retrieved from www. attra.ncat. org, 800-346-9140 (1999).

Dye, D.W.: The inadequacy of the usual determinative tests for identification of Xanthomonas spp. N.Z.J. Sci., 5, 393-416 (1962).

Ezugwu, A.L., T.C. Ezike, A.N. Ibeawuchi, C. A. Nsude, D.I. Udenwobele, S.O.O. Eze, C.U. Anyawu and F.C. Chilaka: Comparative studies on pectinases obtained from Aspergillus fumigatus and Aspergillus niger in submerged fermentation system using pectin extracted from mango, orange and pineapple peels as carbon sources, Nig. J. Biotech., 28, 26-34 (2014).

Fließbach, A., P. Mäder and U. Niggli: Mineralization and microbial assimilation of $14 \mathrm{C}$ labeled straw in soils of organic and 
conventional agricultural systems. Soil. Bio. Biochem., 32, 11311139 (2000).

Garg, N. and A. Mohd: Mango peel as substrate for production of extra cellular polygalacturonase from Aspergillus fumigatus. Indian J. Hortic., 67, 140-143 (2010).

Garg, N., R.A. Ram, R.K. Pathak and A.K. Nagar: Effect of addition of organic fertilizers on microbial load of papaya and guava orchard soils. In: Organic Farming in Horticulture (Eds.: R.K. Pathak, R. Kishun, R.M. Khan and R.A. Ram). ICAR-CISH, Lucknow, p. 275 (2004a).

Garg, N., R.A. Ram, R.K. Pathak and R. Yadav: Effect of different organic treatments on the microbial load of moong (Vigna munga) soil. In: Organic Farming in HHorticulture, (Eds.: R.K. Pathak, R. Kishun, R.M. Khan and R.A. Ram). ICAR-CISH, Lucknow, p277 (2004b).

Gaur, A.C.: Physiological functions of phosphate solubilizing microorganisms. In: Phosphate solubilizing microorganisms as biofertilizers. (Ed.: A.C. Gaur) Omega Scientific Publishers, New Delhi, p. 16-72 (1990)

Giannattasio, M., V. Elena, F. Flavio, A. Sara, Z. Marina, F. Stellin, G. Concheria, P. Stevanato, A. Ertania, S. Nardi, P. Piffanelli, R. Spaccini, P. Mazzei, A. Piccolo and A. Squartini: Microbiological features and bioactivity of a fermented manure product (Preparation 500) used in biodynamic agriculture. J. Microbiol. Biotechnol., 23, 644-651 (2013).

Goldstein, W.A., H.H. Koepf and C.J. Koopmans: Biodynamic preparations, greater root growth and health, stress resistance, and soil organic matter increases are linked. Open Agric., 4, 187-202(2019)

Jackson, M.L.: Soil Chemical Analysis. Prentice Hall of India Pvt. Ltd., New Delhi, p. 498 (1967).

King, C.A.: Community resilience and contemporary agri-ecological systems: Reconnecting people and food, and people with people. Sys. Res. Behav. Sci., 25, 111-124 (2008)

Koepf, H.H.: The Biodynamic Farm. Anthroposophic Press, Hudson, New York, (1989).

Kubilay, M., Ö. Koç, Z.B.B. Ateslier and H.H. Biyik: Purification and characterization of a-amylase produced by Penicillium citrinum HBF62. Afr. J. Biotechnol., 9, 7692-7701 (2010).

Kirchmann, $\mathrm{H}$.: Biological dynamic farming: An occult form of alternative agriculture? J. Agric. Environ. Ethics, 7, 173-187(1994)

Lenhard, G.: The dehydrogenase activity in soil as a measure of the activity of soil microorganisms. Z. Pflanzenernaehr. Dueng. Bodenkd., 73, 1-11 (1956).

Marvin, L.S.: Compendium of Methods for the Microbiological Examination of Foods. $2^{\text {nd }}$ Edn. American Public Health Association, Washington DC, (1984).

Miller, G.L.: Use of dinitrosalicylic acid reagent for determination of reducing sugars. Anal. Chem., 31, 426-428 (1959).

Nallusamy, S., A.A. Zadjali, S.A. Bahry, A. Elshafie and E.A. Eltayeb: Isolation and characterization of cellulolytic Bacillus licheniformis from compost. Afr. J. Biotechnol., 15, 2434-2446 (2016).

Nene, Y.L.: A critical discussion on the methods currently recommended to support organic crop farming in India. Asian Agri. Hist., 21, 267$285(2017)$.

Pandey, J. and A. Singh: Opportunities and constraints in organic farming:An Indian perspective. J. Sci. Res., 56, 47-72 (2012).

Pathak, R.K., R.A. Ram, N. Garg, R. Kishun, S.R. Bhriguvanshi and S. Sharma: Critical review of indigeous technologies for organic farming in horticulture crops. Org. Farm News Let., 6, 3-16 (2010).

Panse, V.G. and P.V. Sukhatme: Statistical Methods for Agricultural Workers. Indian Council of Agricultural Research, New Delhi, p. 381 (1967).
Pedras, M.S.C. and M.R. Park: Metabolite diversity in the plant pathogen Alternaria brassicicola: Factors affecting production of brassicicolin A, depudecin, phomapyrone A and other metabolites, Mycologia, 107,1138-1150 (2015).

Ponzio, C., Gangatharan, R. and D. Neri: Organic and biodynamic agriculture: A review in relation to sustainability. Int. J. Plant Soil Sci., 2, 95-110 (2013).

Proctor, P.: The biodynamic preparations: New Directions for Farming and Gardening in New Zealand. New Zealand Biodynamic Association. Biodynamics., Random House, Auckland, New Zealand, p. 106 (1989)

Radha, T.K. and D.L.N. Rao: Plant growth promoting bacteria from cow dung based biodynamic preparations. Indian J. Microbiol., 54 413-418 (2014).

Ram, R.A., S.R. Bhriguvanshi, N. Garg and R.K. Pathak: Studies on organic production of Guava (Psidium Guajava L.) cv. Allahabad Safeda. Acta. Hortic., 735, 375-379 (2007).

Rana, M., K.P. Raverkar, N. Pareek, R. Chandra and D.K. Singh: Impact of biodynamic preparations and panchgavyain organically managed cropping systems comprising legumes on soil biological health. Legume Res., 38, 219-228 (2015).

Raupp, J. and U.J. Konig: Biodynamic preparations cause opposite yield effects depending upon yield levels. Biol. Agric. Hortic., 13, 175$188(1996)$

Reddy, B.S.: Organic farming: Status, issues and prospects - A review. Agric. Econ. Res. Rev., 23, 343-358 (2010)

Reeve, J.R., L. Carpenter-Boggs and H. Sehmsdorf: Sustainible agriculture: A case study of a small Lopez Island farm. Agric. Syst., 104, 572-579 (2011).

Rehman H.U., S.N. Naveed, A. Afsheen, M.A. Nawaz, A.H. Baloch and S.A.U. Qader: Morphological and molecular based identification of pectinase producing Bacillus licheniformis from rotten vegetable. J. Genet. Eng. Biotechnol., 13, 139-144 (2015).

Rupela, O.P., S. Gopalakrishnan, M. Krajewski and M. Sriveni: A novel method for the identification and enumeration of microorganisms with potential for suppressing fungal plant pathogens. Biol. Fertil. Soils, 39, 131-134 (2003).

Schnurer, J. and T. Rosswall: Fluorescein diacetate hydrolysis as a measure of total microbial activity in soil and litter. Appl. Environ. Microbiol., 43,1256-1261(1982).

Schwyn, B. and J.B. Neilands: Universal chemical assay for the detection and determination of siderophore. Ana. Biochem., 160,47-56 (1987).

Selvaraj, N., B. Anita, B. Anusha and M.G. Saraswathi: Organic horticulture: Creating a more sustainable farming (ISBN: 8190407201). Horticulture Research Station, Tamil Nadu Agriculture University, p. 525 (2006).

Shende, S.T., R.G. Aple and T. Singh: Influence of Azotobacter on germination of rice and cotton seeds. Curr. Sci., 46, $675-676$ (1977).

Speth, J.G.: On the road to Rio and to sustainability. Environ. Sci. Technol., 26, 1075-1076 (1992).

Tamura, K., D. Peterson, N. Peterson, G. Stecher, M. Nei and S. Kumar: MEGA5: Molecular evolutionary genetics analysis using maximum likelihood, evolutionary distance, and maximum parsimony methods. Mol. Biol. Evol., 28, 2731-2739 (2011).

Valdez, R.E. and P. Fernandez: Productivity and seed quality of rice (Oryza sativa L.) cultivars grown under synthetic organic fertilizer and biodynamic farming practices. Philipp. J. Crop Sci., 33, 37-58 (2008).

Veeresh, S.J., J. Narayana and J.A. Teixeira da Sliva: Influence of Jeevamrutha (Biodynamic formulations) on agro industrial waste 
vermicomposting. Dyn. Soil Dyn. Plant., 4, 96-99 (2010).

Vengadaramana, A., S. Balakumar and A. Vasanthy: Improving aamylase production by Bacillus licheniformis ATCC 6346 with local nitrogen sources and amino acids supplementations. Arch. App. Sci. Res., 3, 87-97(2011).

Wood, T.M. and K.M. Bhat: Methods for measuring cellulase activities. In:
Methods of Enzymology Biomass Part A- Cellulose Hemicelluloses. Academic press, New York, 160, p. 87 (1988).

Yadav, J., J.P. Verma and K.N. Tiwari: Effect of plant growth promoting rhizobacteria on seed germination and plant growth of chickpea (Cicer arietinum L.) under in-vitro conditions. BFAl, 2, 15-18 (2010). 